\title{
Glaciochemical dating of an ice core from upper Grenzgletscher (4200 m a.s.1.)
}

\author{
Anja Eighler, ${ }^{1,2}$ Margit Sahwikowski, ${ }^{1}$ Heinz W. Gäggeler,,${ }^{1,2}$ Verena Furrer, ${ }^{1}$ \\ Hans-Arno Synal, ${ }^{3}$ Jürg Beer, ${ }^{4}$ Matthias Saurer, ${ }^{1}$ Martin Funk ${ }^{5}$ \\ ${ }^{1}$ Paul Scherrer Institute, CH-5232 Villigen PSI, Switzerland \\ ${ }^{2}$ Department of Chemistry and Biochemistry, University of Bern, Freiestrasse 3, CH-3012 Bern, Switzerland \\ ${ }^{3}$ Paul Scherrer Institute, c/o ETH Hönggerberg, CH-8093 Zürich, Switzerland \\ ${ }^{4}$ Swiss Federal Institute for Environmental Science and Technology (EAWAG), CH-8600 Dübendorf, Switzerland \\ ${ }^{5}$ Versuchsanstalt für Wasserbau, Hydrologie und Glaziologie, Eidgenössische Technische Hochschule (ETH), CH-8092 Zürich, Switzerland
}

\begin{abstract}
One crucial condition for the interpretation of ice-core records is the establishment of an accurate time-scale. This task is especially difficult for glacier sites in a complex topography such as the Alps, due to the often irregular deposition of fresh precipitation. In this work, dating techniques were applied to an Alpine ice core from upper Grenzgletscher, Monte Rosa massif (4200 m a.s.l.), representing about two-thirds of the total glacier thickness. They are based on (i) the radioactive decay of the isotope ${ }^{210} \mathrm{~Pb}$, (ii) seasonally varying signals such as the concentrations of $\mathrm{NH}_{4}{ }^{+}$and the isotopic ratio $\delta^{18} \mathrm{O}$, and (iii) stratigraphic markers from Saharan dust falls, atmospheric nuclear weapon tests and the reactor accident in Chernobyl. From the combined application of these dating methods, a time period of 1937-94 covered by the ice core was derived. Dating uncertainty is $<1$ year for the period 1970-94 and \pm 2 years for the period 1937-69. The observed thinning of the annual layers as a function of depth could be well described by a simple kinematic glacier flow model.
\end{abstract}

\section{INTRODUCTION}

Cold, mid-latitude glaciers represent a natural archive, well suited for studying past environmental and climatic conditions. However, a correct interpretation of ice-core records can only be performed based on a precise dating. For the time period covered by Alpine ice cores ranging from decades to thousands of years, a number of dating methods are available. The choice of the most appropriate dating method is dependent on the time-scale and accuracy requirements. A dating method frequently applied is the use of the decay of radioactive isotopes. As an example, dating with ${ }^{210} \mathrm{~Pb}\left(t_{\frac{1}{2}}=22.3 \mathrm{a}\right)$, a product of the natural ${ }^{238} \mathrm{U}$ decay series, has been successfully applied to Alpine ice cores for time-scales of about 100 years (Gäggeler and others, 1983).

A very precise method involves dating by successive annual-layer counting, similar to the age determination of trees by counting the annual rings. In contrast to tree rings, one annual layer in a glacier may reach a thickness of several meters. However, the application of annual-layer counting requires a regular distribution of the precipitation throughout the year, and a pronounced seasonal variation of a tracer species measured in the ice core. One example is the isotopic ratio ${ }^{18} \mathrm{O} /{ }^{16} \mathrm{O}$ of the water molecules in precipitation, showing a strong annual variation due to the dependence on the condensation temperature (Dansgaard, 1964). Another example is the concentration of aerosolrelated species in snow (e.g. $\mathrm{NH}_{4}{ }^{+}, \mathrm{SO}_{4}{ }^{2-}$ and $\mathrm{NO}_{3}{ }^{-}$) which can exhibit clear summer maxima at high-Alpine sites (Schwikowski and others, 1999a). The dating by layer count- ing becomes difficult with increasing depth of the ice core due to the thinning of the annual layers.

Another approach for dating is the use of debris originating from well-known events. These reference horizons are identified by unusual concentrations of given species. The best-suited markers are chemical impurities from Saharan dust falls (Wagenbach and Geis, 1989), volcanic eruptions (Döscher, 1996), forest fires (Savarino and Legrand, 1998) or the radioactive debris from atmospheric nuclear weapons testing in the 1950s and early 1960s, as well as the reactor accident in Chernobyl in 1986.

Due to the uncertainties inherent in each individual dating method mentioned, it is more promising to combine several methods for establishing a precise age-depth relation for ice cores. In this work we describe the dating of an Alpine ice core from upper Grenzgletscher, Monte Rosa massif, Switzerland, by such a multiparametric approach.

A large number of studies were performed at upper Grenzgletscher in the 1970s and early 1980s (see, e.g., Oeschger and others, 1978; Schotterer and others, 1985; Wagenbach and others, 1988). The Colle Gnifetti saddle (4450 m a.s.l.), where the ice cores were drilled, is characterized by low net annual accumulation rates, reaching approximately $30 \mathrm{~cm}$ w.e. $\mathrm{a}^{-1}$ for the central saddle (Gäggeler and others, 1983). The investigations demonstrated that parts of the annual precipitation, mainly during winter, are removed by wind erosion. The advantage of the low annual accumulation rates at this site is that a much longer time period can be accessed than at high-accumulation sites. The concentration increase of trace species in snow due to the enhanced anthropogenic 
emissions of their precursors, between pre-industrial times and the 1970s, has been shown in several studies (see, e.g., Schotterer and others, 1985; Wagenbach and others, 1988; Döscher and others, 1995b, 1996; Lavanchy and others, 1999; Schwikowski and others, 1999b).

Due to their extent the Alps act as a barrier for air-mass flow, and therefore a north-south gradient of the air-pollution impact on the high-Alpine environment is expected. In order to assess the geographical and seasonal trends of the deposition of trace components and to identify the source regions of air pollution, glaciochemical records retrieved from glaciers located in the northern and southern part of the Alps are required. However, a comparison on an annual time-scale, for instance, necessitates well-dated high-resolution deposition records. Since such records are already available from the northern Alpine chain (from Fiescherhorn glacier (3890 m a.s.l. (see Fig. 1); time period 1946-88; Schwikowski and others, 1999a)), an equally suitable site was sought in the southern Alpine chain. Thus, the initial aim of a new drilling campaign at Grenzgletscher in 1994 was to recover an ice core from a high-accumulation site in the southern Swiss Alps. The accurate dating of the Grenzgletscher ice core is described here; the investigation of geographical and seasonal trends will be the subject of a future study.

\section{EXPERIMENTAL}

\subsection{Ice-core drilling}

In October 1994 an ice core $125 \mathrm{~m}$ long was recovered from upper Grenzgletscher (4200 m a.s.l.; 45 $55^{\prime} 28^{\prime \prime} \mathrm{N}, 7^{\circ} 52^{\prime} 3^{\prime \prime} \mathrm{E}$, Swiss coordinates 633 250/085 890) at a site presumably located on the flowline of Colle Gnifetti in the Monte Rosa massif (see Fig. 1). This drilling site was selected because wind

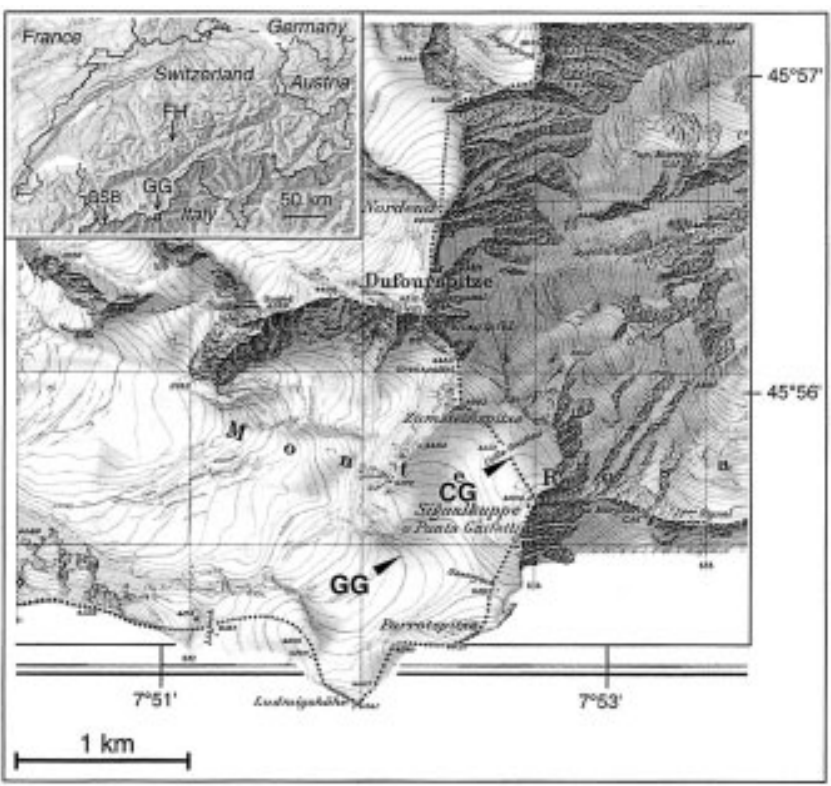

Fig. 1. Drilling sites at Grenzgletscher (GG, 1994; 4200 ma.s.l.) and at Colle Gnifetti (CG, 1982; 4450 m a.s.l.), Monte Rosa massif. Reproduced with permission of the Swiss Federal Office of Topography (BA4592). International coordinates are included. Inset shows a topographic map of Switzerland where the locations of Grenzgletscher and of the weather station at Col du Grand St Bernard (GSB) in the southern Swiss Alps, and the Fiescherhorn (FH) in the northern Swiss Alps are indicated. erosion of the accumulated precipitation is much less than at the Colle Gnifetti saddle. Analyses of shallow firn cores from the area of upper Grenzgletscher (Döscher, 1996; Gäggeler and others, 1997) indicated an annual accumulation rate of about $2 \mathrm{~m}$ w.e. at the drilling site.

During the campaign, ice-core sections $(0.5-0.8 \mathrm{~m}$ long) with a diameter of $7.8 \mathrm{~cm}$ were electromechanically drilled (for details see Gäggeler and others, 1997), packed and sealed in polyethylene tubes in the field and kept frozen in a cold room at $-25^{\circ} \mathrm{C}$ until sample preparation.

\subsection{Radar soundings}

Measurements of the glacier thickness by radar soundings were performed at the drill site in order to investigate the flow behaviour of the glacier and to predict the source area of the drilled firn and ice (Vonder Mühll and Funk, unpublished). The results of the radar soundings show an increase of the glacier thickness and a slope of the glacier bed down along the flowline of Grenzgletscher from east-northeast (ENE) to west-southwest (WSW) (Figs 2 and 3). The glacier thickness doubles from 100 to $200 \mathrm{~m}$ within a horizontal distance of $400 \mathrm{~m}$. We assume that the glacier thickness at the drilling site is approximately $190 \mathrm{~m}$. With a relatively flat glacier geometry

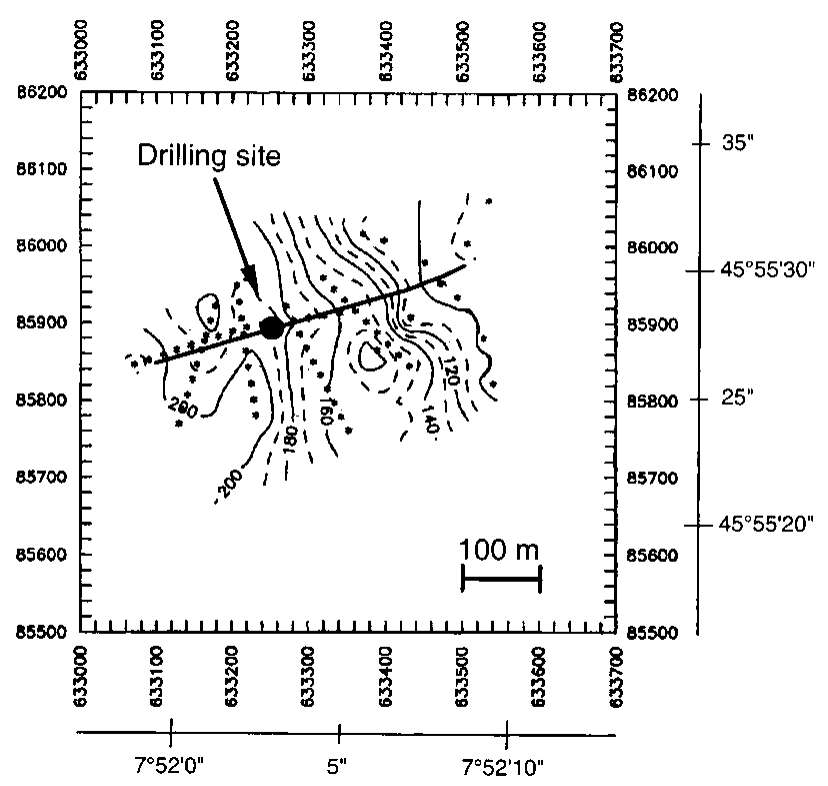

Fig. 2. Glacier thickness (in meters) at the drilling site of upper Grenzgletscher interpolated from radar profiles (stars) (after Vonder Mühll and Funk, unpublished), along with the flowline used in Figure 3 (thick line). Swiss and international coordinates are given.

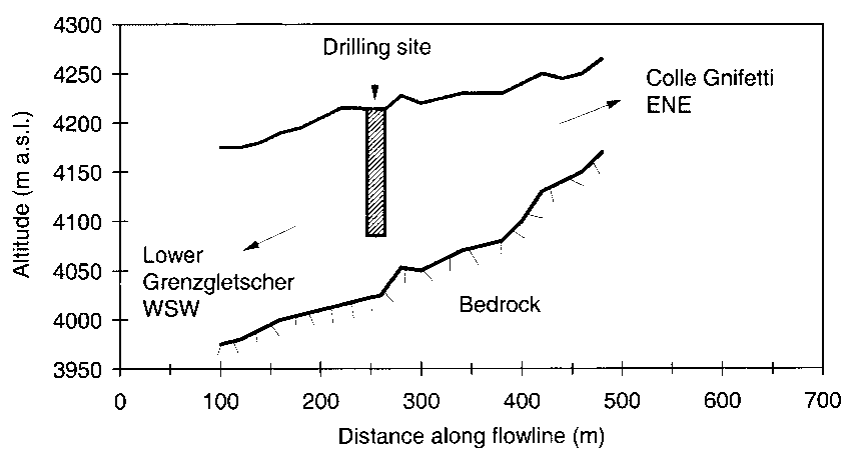

Fig. 3. Schematic cross-section of upper Grenzgletscher at the drilling site. 
(slope of about $10^{\circ}$; Fig. 3), upper Grenzgletscher is well suited to serve as an archive for atmospheric species.

\subsection{Measurement of borehole temperatures}

For the preservation of ice-core records of water-soluble trace components, the absence of meltwater percolation and temperate firn is essential, since the inflow of meltwater could change the initial composition of firn and ice. Measurements of borehole temperatures at the drilling site were carried out using thermistor chains (personal communication from S. Suter, 1999). The measured continuous negative borehole temperatures (Fig. 4) indicate that Grenzgletscher consists of cold firn and ice down to at least $4000 \mathrm{~m}$ a.s.l.. A relatively high temperature of $-0.4^{\circ} \mathrm{C}$ at $2.5 \mathrm{~m}$ w.e. depth shows that the upper firn layer was nearly temperate down to this depth: a result of the unusually high temperatures in summer 1994. We conclude that the drilling site belongs to the cold infiltration zone where meltwater may be present in the upper firn layer.

Conspicuous in the temperature profile is the local temperature maximum of about $-1^{\circ} \mathrm{C}$ at $18 \mathrm{~m}$ w.e. depth. It has been suggested that this temperature anomaly is due to meltwater inflow at $11-12 \mathrm{~m}$ w.e. depth, most probably through a crevasse system in the glacier (Eichler and others, in press). Additionally, draining of the meltwater at 20-24 mw.e. depth was supposed. Meltwater percolation led to a preferential leaching of various species. Concentrations of some ions (e.g. $\mathrm{SO}_{4}{ }^{2-}, \mathrm{Ca}^{2+}, \mathrm{Na}^{+}$) were drastically reduced, whereas species discussed in this work $\left(\mathrm{NH}_{4}{ }^{+}, \delta^{18} \mathrm{O}\right.$ and ${ }^{210} \mathrm{~Pb}$ ) were preserved (see also Fig. 5). The preferential leaching was attributed to fractionation between different species occurring during snow metamorphic processes

\section{$\mathrm{T}\left({ }^{\circ} \mathrm{C}\right)$}
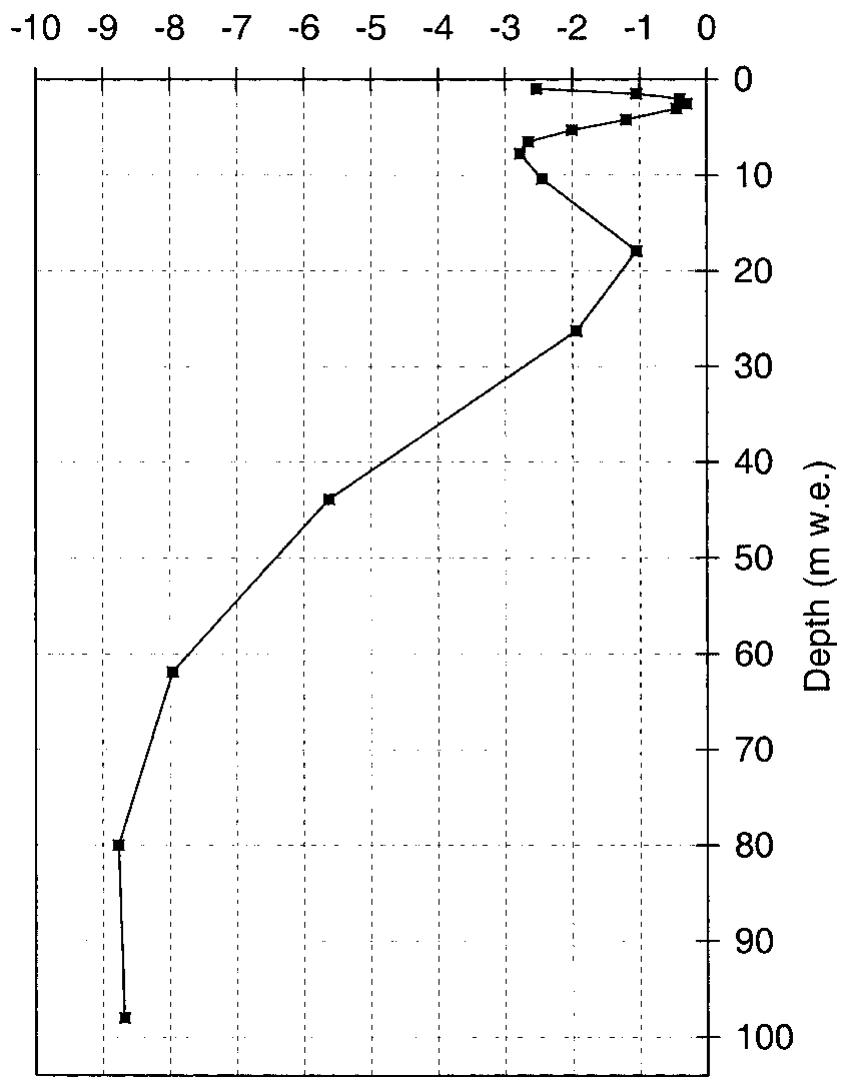

Fig. 4. Borehole temperatures along the drilling (personal communication from S. Suter, 1999). The ice-core depth of $104 \mathrm{~m}$ w.e. represents the total length of $125 \mathrm{~m}$.
(Eichler and others, in press). Thus, the methods used in this study can be applied for dating glaciers even where partial percolation of meltwater has occurred. The borehole temperature decreased below $18 \mathrm{mw}$.e. down to $-9^{\circ} \mathrm{C}$ in $80 \mathrm{~m}$ w.e. depth, indicating an inflow of colder ice, presumably from the area of Colle Gnifetti.

\subsection{Sample preparation}

In the cold room of the Paul Scherrer Institute, each core section with a length up to $55 \mathrm{~cm}$ was photographed for documentation of stratigraphic characteristics (e.g. ice lenses, dust layers). Sectioning and decontamination of the firn and ice were carried out using a modified band-saw setup (stainless-steel blades; tabletops and saw guides covered with Teflon) which was regularly cleaned with acetone (Merck). The ice-core sections were cut into $5 \mathrm{~cm}$ pieces. Outer parts, which might have been chemically contaminated by the drill and the plastic storage bag, were used to analyze the isotopes ${ }^{210} \mathrm{~Pb},{ }^{3} \mathrm{H},{ }^{137} \mathrm{Cs},{ }^{36} \mathrm{Cl}$ and the isotopic ratio $\delta^{18} \mathrm{O}$. From the inner parts the concentrations of the main ionic species, $\mathrm{pH}$ and conductivity were determined.

Due to the low concentrations of chemical species in ice and firn, materials in contact with the samples had to be very carefully cleaned. Thus, all storage bags, instruments and sample vials used were rinsed several times with ultrapure water (18 $\mathrm{M} \Omega \mathrm{cm}$ quality).

\subsection{Chemical and isotopic analyses}

The quantitative analysis of the $\mathrm{NH}_{4}{ }^{+}$concentrations in the firn and ice samples (sample volume $1 \mathrm{~mL}$ ) was performed

${ }^{210} \mathrm{~Pb}\left(\mathrm{mBq} \mathrm{kg}{ }^{-1}\right)$

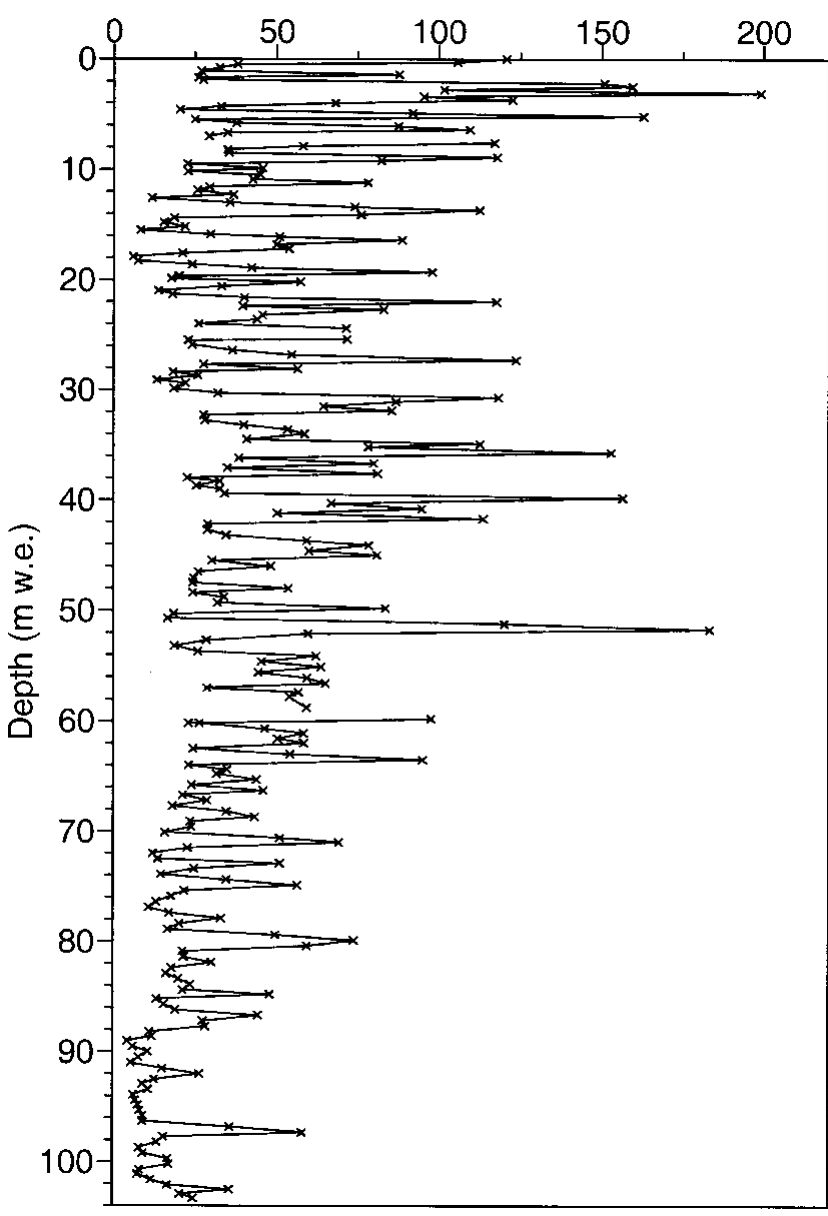

Fig. 5. Record of the ${ }^{210} \mathrm{~Pb}$ activity along the ice core. 
by ion chromatography (IC) with conductivity detection (Döscher and others, 1995a; Eichler, unpublished).

The $\mathrm{pH}$ was determined using an 8103 Orion Electrode coupled to a Metrohm pH meter 605 (sample volume $1 \mathrm{~mL}$, addition of $10 \mu \mathrm{L} 1 \mathrm{M} \mathrm{KCl}$ ) (Eichler, unpublished).

The analysis of the isotopic ratio $\delta^{18} \mathrm{O}$ (defined as the relative deviation of the ${ }^{18} \mathrm{O} /{ }^{16} \mathrm{O}$ ratio of the sample from the Vienna standard mean ocean water) was carried out by equilibration of a $5 \mathrm{~mL}$ sample with $\mathrm{CO}_{2}$ gas ( 0.8 bar) over $8 \mathrm{~h}\left(T=19^{\circ} \mathrm{C}\right)\left(\right.$ Epstein and Mayeda, 1953). The $\mathrm{C}^{18} \mathrm{O}^{16} \mathrm{O} /$ $\mathrm{C}^{16} \mathrm{O}_{2}$ ratio of the gas was measured using an isotope-ratio mass spectrometer (delta-S, Finnigan MAT).

The ${ }^{210} \mathrm{~Pb}$ activity (sample volume $200 \mathrm{~mL}$ ) was indirectly determined over the activity of its granddaughter nuclide ${ }^{210}$ Po electrolytically deposited on Ag plates. The ${ }^{210}$ Po activity was determined by measuring its $\alpha$ decay at an energy of $5.3 \mathrm{MeV}$ (Gäggeler and others, 1983; Eichler, unpublished).

For the determination of the ${ }^{137} \mathrm{Cs}$ activity, the sample (1 L) was passed through a cation exchange column. Then the exchange resin containing the ${ }^{137} \mathrm{Cs}^{+}$was placed in an HPGe $\gamma$-borehole detector, and the ${ }^{137} \mathrm{Cs}$ activity was measured via its $\gamma$-decay energy of $662 \mathrm{keV}$.

The ${ }^{3} \mathrm{H}$ content of the samples (sample volume $10-70 \mathrm{~mL}$ ) was determined by direct $\beta$ measurement in a liquid-scintillation spectrometer (Schotterer and others, 1998).

The analysis of the isotope ${ }^{36} \mathrm{Cl}$ was performed by accelerator mass spectrometry (AMS). For this purpose a $\mathrm{Cl}$ carrier was added to the sample (about $1 \mathrm{~L}$ ). The $\mathrm{Cl}^{-}$of the sample was precipitated as $\mathrm{AgCl}$, dried and pressed into a $\mathrm{Cu}(\mathrm{Ta})$ target. Afterwards, the ratio ${ }^{36} \mathrm{Cl} / \mathrm{Cl}$ was determined by AMS at the Zürich facility (Synal and others, 1994, 1997).

\section{RESULTS AND DISGUSSION}

\subsection{Dating by radioactive decay of ${ }^{210} \mathrm{~Pb}$}

The radioactive isotope ${ }^{210} \mathrm{~Pb}$ can be used for dating glacier ice on a century time-scale. Gäggeler and others (1983) and von Gunten and others (1983) showed that the ${ }^{210} \mathrm{~Pb}$ method can even be used for dating temperate glaciers and glacier sites with an irregular deposition of precipitation, where most of the conventional dating methods cannot be applied.

${ }^{210} \mathrm{~Pb}$ with a half-life of 22.3 years is a decay product of ${ }^{222} \mathrm{Rn}\left(t_{\frac{1}{2}}=3.83 \mathrm{~d}\right)$ which emanates continuously from the Earth's crust into the atmosphere. Attached to aerosol particles, ${ }^{210} \mathrm{~Pb}$ can reach the glacier surface by dry or wet deposition after a residence time in the atmosphere of a few days to a few weeks. In firn and ice the activity of ${ }^{210} \mathrm{~Pb}$ decreases with increasing depth due to its radioactive decay. The exponential decay of the isotope can be used for dating under the following assumptions (Gäggeler and others, 1983):

(a) constant input of ${ }^{210} \mathrm{~Pb}$

(b) no transport of the initial deposited ${ }^{210} \mathrm{~Pb}$ in firn and ice (e.g. by meltwater running through the glacier).

We used the ${ }^{210} \mathrm{~Pb}$ method for a first estimation of the time period covered by the Grenzgletscher core. The record of the ${ }^{210} \mathrm{~Pb}$ activities measured along the ice core is shown in Figure 5. We observed a decrease of the ${ }^{210} \mathrm{~Pb}$ activity with depth superimposed on strong fluctuations. These fluctuations of the measured ${ }^{210} \mathrm{~Pb}$ activities indicate that the input of ${ }^{210} \mathrm{~Pb}$ at this high-Alpine site is not constant throughout the year, in contradiction of assumption (a) above. Von Gunten and
Moser (1993) illustrated that ${ }^{210} \mathrm{~Pb}$ activities at low altitudes (Fribourg, Switzerland) do not exhibit a pronounced seasonal pattern, indicating that emissions of ${ }^{210} \mathrm{~Pb}$ from rocks and soils are independent of the season. On the other hand, strong seasonal variations of the ${ }^{210} \mathrm{~Pb}$ activity, with maximum values in August/September, have been observed at the high-Alpine research station Jungfraujoch, Switzerland (3450 m a.s.l.; Gäggeler, 1995). These were attributed to seasonal variations in the transport of pollutants to the high-elevation sites. A higher frequency of convective weather types in summer yields a stronger vertical transport of aerosol-rich air from the atmospheric boundary layer to the high-Alpine sites. Therefore, higher concentrations of trace species are found in the summer snow, whereas, due to a suppression of the vertical motion by the great stability of the atmosphere, the concentrations in winter are low (Lugauer and others, 1998).

Dating of the Grenzgletscher ice core, based on the radioactive decay of ${ }^{210} \mathrm{~Pb}$, is shown in Figure 6. For this purpose we used mean values of the measured ${ }^{210} \mathrm{~Pb}$ activity over sections of about $10 \mathrm{mw}$.e., thus averaging the described transport fluctuations. It is remarkable that a decrease of ${ }^{210} \mathrm{~Pb}$ activity due to decay is not visible in the part from 15 to $55 \mathrm{~m}$ w.e. This indicates that the input of ${ }^{210} \mathrm{~Pb}$ at the glacier site has not been constant over the last 60 years. We attribute this phenomenon to a stronger input of ${ }^{210} \mathrm{~Pb}$ in the $1970 \mathrm{~s}$. Concurrent with the high ${ }^{210} \mathrm{~Pb}$ activities, concentration records of the species sulphate, nitrate and ammonium showed maximum values at 50-55 m w.e. depth, due to enhanced emissions of $\mathrm{SO}_{2}, \mathrm{NOx}$ and $\mathrm{NH}_{3}$ from anthropogenic activities. We assume that during this period larger amounts of ${ }^{210} \mathrm{~Pb}$ were transported to the high-Alpine sites because of increased concentrations of aerosol particles acting as transport vehicles.

From the linear regression plot of the logarithmic ${ }^{210} \mathrm{~Pb}$ activities against depth (solid line, Fig. 6) we derived an age for the deepest part of the ice core of $55 \pm 7$ years with respect to the drilling date. The value of the axis intercept ( $85 \pm$ $10 \mathrm{mBq} \mathrm{kg}^{-1}$ ) corresponds to the ${ }^{210} \mathrm{~Pb}$ activity at the surface of Grenzgletscher. This result agrees well with the ${ }^{210} \mathrm{~Pb}$ surface activity obtained from other Alpine sites: Colle Gnifetti (4450 m a.s.l.) $85 \pm 27 \mathrm{mBq} \mathrm{kg}^{-1}$ (Füeg, unpubished); Jungfraujoch (3545 ma.s.l.) $78 \pm 5 \mathrm{mBq} \mathrm{kg}^{-1} \quad$ (Schotterer and others, 1977); Vernagtferner (3150 m a.s.l.) $83 \pm 17 \mathrm{mBq} \mathrm{kg}^{-1}$ (von Gunten and others, 1983).

From the slope of the regression line, we derived a mean annual accumulation rate of $1.9 \mathrm{~m}$ w.e.. This value does not include a thinning of the annual-layer thickness with depth

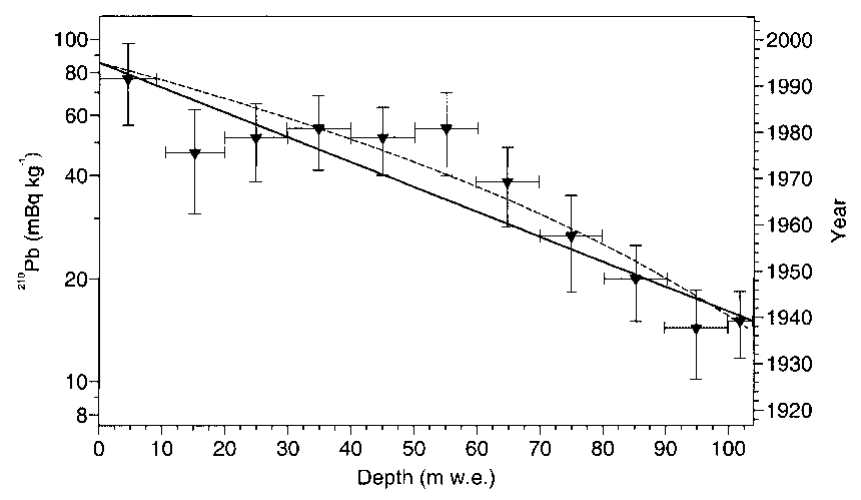

Fig. 6.10 m w.e. mean ${ }^{210} \mathrm{~Pb}$ activity (triangles, lefthand logarithmic scale) together with a linear trend line (solid line) and a fitted function after Equation (1) (dashed line) vs depth of the ice core and the calculated age (righthand scale). 
(see section 3.4). The estimated age-depth relation (Fig. 6, solid line, righthand scale) has uncertainties of \pm 7 years.

\subsection{Dating by seasonally varying signals}

\section{$\mathrm{NH}_{4}^{+}$}

As already pointed out in previous work on Alpine glaciers (e.g. Maupetit and others, 1995; Schwikowski and others, 1999a), $\mathrm{NH}_{4}{ }^{+}$concentrations in high-altitude glacier ice show the most pronounced seasonal pattern of any deposited major ion. This strong seasonal behaviour, with concentrations about one order of magnitude higher in summer precipitation than in winter precipitation, is due to two synergistic effects. First, the gaseous precursor $\mathrm{NH}_{3}$ is mainly emitted into the atmosphere in the warmer months (Asman, 1992) because a high proportion of it (up to $90 \%$ ) originates from agricultural emissions of livestock excreta and of fertilizers. Second, a strong vertical transport of pollutants from the planetary boundary layer to high-Alpine sites occurs mainly in the summer months (see section 3.1).

The record of the $\mathrm{NH}_{4}{ }^{+}$concentration along the $125 \mathrm{~m}$ (104 m w.e.) ice core from Grenzgletscher is shown in Figure 7. Because of poor ice quality, the part between 58 and $60 \mathrm{~m}$ w.e. could not be analyzed. In order to highlight the seasonality, seven-point moving averages were used. The expected seasonal variations are indicated by up to 20 times higher summer than winter concentrations. Reported values were statistically different from the blank value $\left(0.07 \mu \mathrm{eq} \mathrm{L}{ }^{-1}\right)$. Dating was performed by annual-layer counting, revealing

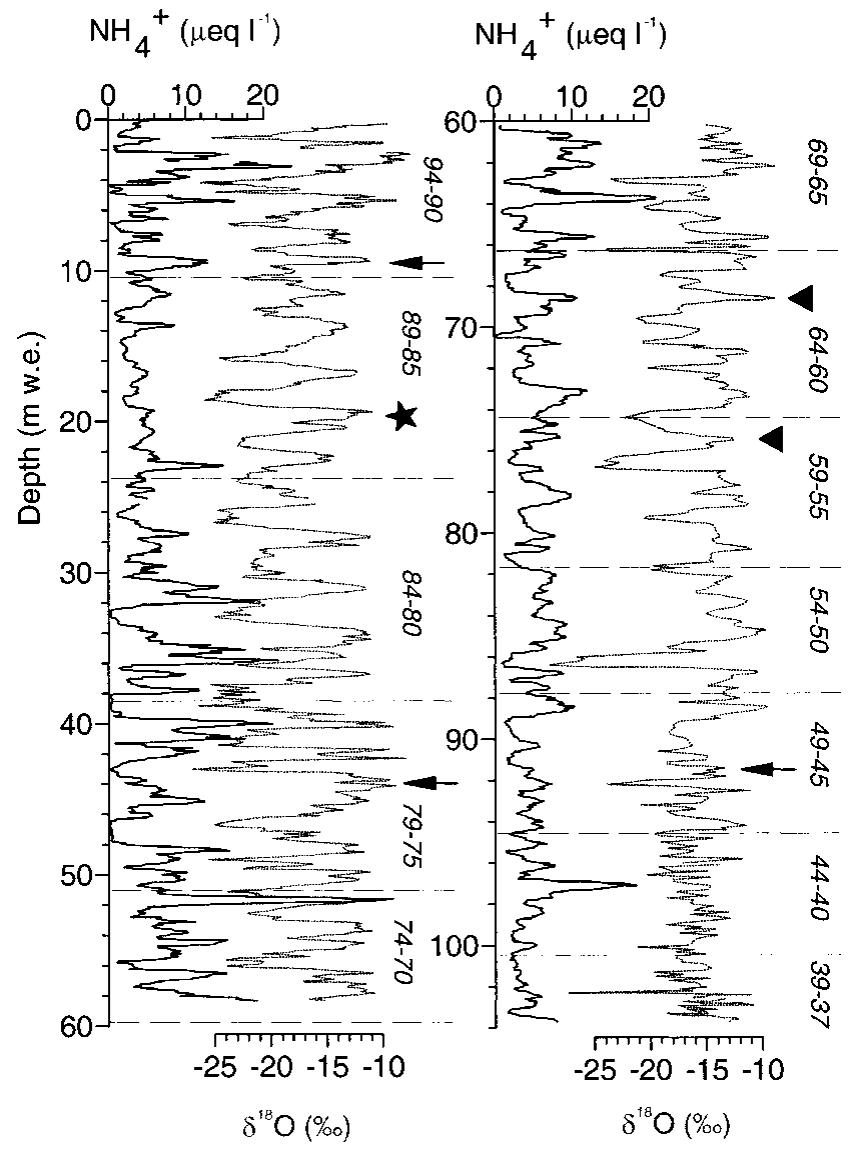

Fig. 7. Records of $\mathrm{NH}_{4}^{+}$(seven-point moving average, solid line) and $\delta^{18} \mathrm{O}$ (dotted line) vs depth of the ice core in mw.e., together with 5 year segments (dashed lines) and six reference horizons (Saharan dust events 1990, 1977, 1947: arrows; Chernobyl accident 1986: star; nuclear weapon tests 1963, 1959: triangles). an age of the deepest part of the core of 57 years with respect to the drilling date. Dating uncertainty is $1-2$ years for each 5 year period because of certain difficulties with the identification of annual layers. Such difficulties were encountered for periods with small precipitation amounts (e.g. winter 1980/81), with relatively high concentrations in winter (e.g. 1982/83) or with low concentrations in summer (e.g. 1980). High concentrations in winter can be related to cyclonic weather types, whereas summer minima are due to the advection of fresh maritime air from the Atlantic (Lugauer and others, 1998). A cumulative dating uncertainty of 12-24 years is finally observed from counting annual $\mathrm{NH}_{4}{ }^{+}$layers.

\section{$\delta^{18} \mathrm{O}$}

Temperature- and vapour-pressure-dependent fractionation of the main isotopic components of water $\mathrm{H}_{2}{ }^{16} \mathrm{O}$ and $\mathrm{H}_{2}{ }^{18} \mathrm{O}$ during evaporation and condensation processes in the hydrological cycle causes lower $\delta^{18} \mathrm{O}$ values in winter and higher values in summer precipitation (Dansgaard and others, 1973). The correlation between monthly mean $\delta^{18} \mathrm{O}$ values of precipitation and the atmospheric temperatures at high-Alpine sites was described by Schotterer and others (1997), for instance. The $\delta^{18} \mathrm{O}$ record of the ice core from Grenzgletscher is shown in Figure 7 against depth (dotted line). Strong seasonal patterns with maximum values of up to $-10 \%$ and minimum values of $-25 \%$ corresponding to deposited summer and winter precipitation, respectively, are observed. These are typical values for Alpine precipitation at these altitudes (Schotterer and others, 1997). The dating performed by the annual-layer counting using the varying $\delta^{18} \mathrm{O}$ signal has an uncertainty of \pm 1 year in the upper part of the ice core ( $<58 \mathrm{~m}$ w.e.). Due to the thinning of the annual layers and the smoothing of the signal with depth by diffusion processes (Johnsen, 1977), the dating error is about 1 year for each 5 year period between 60 and $90 \mathrm{~m}$ w.e. Thus, cumulative dating uncertainty is about 6 years for the upper $90 \mathrm{~m}$ w.e. Dating is hardly possible for the deepest part (>90 m w.e.).

However, a combined evaluation of the $\mathrm{NH}_{4}{ }^{+}$and $\delta^{18} \mathrm{O}$ profiles improved the dating precision significantly. Generally, in time periods poorly resolved by $\mathrm{NH}_{4}{ }^{+}, \delta^{18} \mathrm{O}$ seasonal layers were well produced and vice versa (see, e.g., time periods $84-80$ and $44-40)$. The resulting uncertainty is \pm 1 year for the period 1970-94 and \pm 3 years for the period $1937-69$.

The strong seasonal variation of $\mathrm{NH}_{4}^{+}$concentrations together with the $\delta^{18} \mathrm{O}$ values indicate that precipitation at the drilling site is regularly distributed throughout the year. In order to examine if the measured amount of precipitation at Grenzgletscher is representative for this part of the Alps, we compared the net annual accumulation rate deduced from the ice core with annual precipitation data of the $50 \mathrm{~km}$ distant weather station at Col du Grand St Bernard (2469 m a.s.l.; see Fig. 1). This is the closest high-mountain weather station, with the longest precipitation series in the higher European Alps (Wanner and others, 1997). Reasonable agreement was found in the trend for the period 1977-93 ( $r=0.7$; Fig. 8). This time period was selected because the thinning of annual layers in this part of the glacier is negligible. A mean precipitation rate of $2.4 \pm 0.3 \mathrm{~m}$ w.e was registered at the Col du Grand St Bernard station, and $2.7 \pm 0.4 \mathrm{~m}$ w.e. at Grenzgletscher, suggesting that the accumulated precipitation at Grenzgletscher corresponds roughly to the actually fallen precipitation at this site. Thus, wind erosion or drift seems to be of much less importance than at more exposed saddle sites, such as Colle Gnifetti. Precipita- 


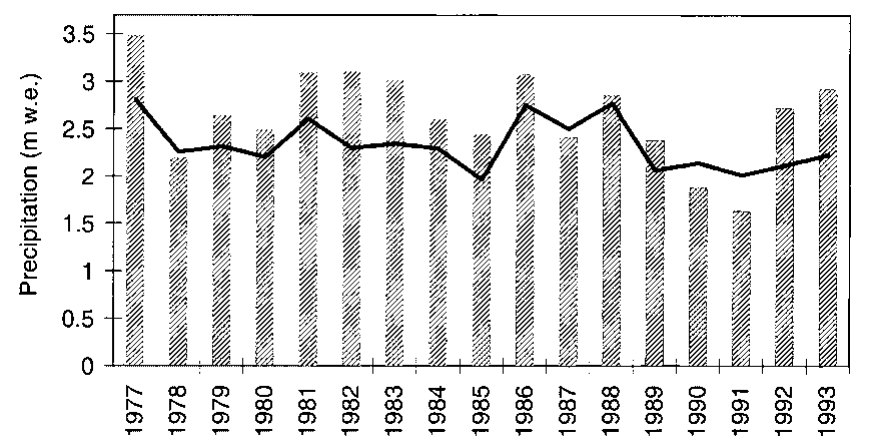

Fig. 8. Comparison of the annual accumulation rate calculated from ice-core data (columns) with the annual precipitation measured at the weather station Col du Grand St Bernard (line), 1977-93.

tion data from the weather station during the period 1935-94 show that precipitation in this area is nearly uniformly distributed throughout the year. Exceptions (e.g. seasons with extremely small or large amounts of precipitation) can sometimes be clearly identified from the measured $\delta^{18} \mathrm{O}$ record. For instance, the pronounced $\delta^{18} \mathrm{O}$ minimum of $-27 \%$ at $86 \mathrm{~m}$ w.e. depth (see Fig. 7) is due to the well-known heavy snowfall in January and February 1951 causing a large number of avalanches (Pfister, 1999).

\subsection{Dating by stratigraphic markers}

\section{Saharan dust falls}

Mineral dust originating from the Sahara can be transported over a distance of several thousand kilometers towards the Alps. As already known from studies at highAlpine sites (e.g. at Colle Gnifetti (Wagenbach and Geis, 1989) and Mont Blanc, French Alps (de Angelis and Gaudichet, 1991)), the portion of Saharan dust amounts to approximately two-thirds of the overall mineral dust content. Mineralogical composition of Saharan dust can vary with the source region in Africa. A pronounced abundance of carbonates (as calcite) (Schütz and Sebert, 1987), as well as high contents of the minerals quartz, gypsum, muscovite, anorthite and montmorillonite (Schwikowski and others, 1995), were detected. Because of the high amount of basic minerals in Saharan dust aerosols, Saharan dust-bearing snow layers are marked not only by the often occurring yellow-orange colouring, but also chemically by a high $\mathrm{Ca}^{2+}$ content and increased $\mathrm{pH}$ values. $\mathrm{Ca}^{2+} / \mathrm{H}^{+}$concentration ratios along the ice core from Grenzgletscher are presented in Figure 9. Three maxima of the $\mathrm{Ca}^{2+} / \mathrm{H}^{+}$concentration ratio are attributed to intense Saharan dust-fall events described in the literature: March

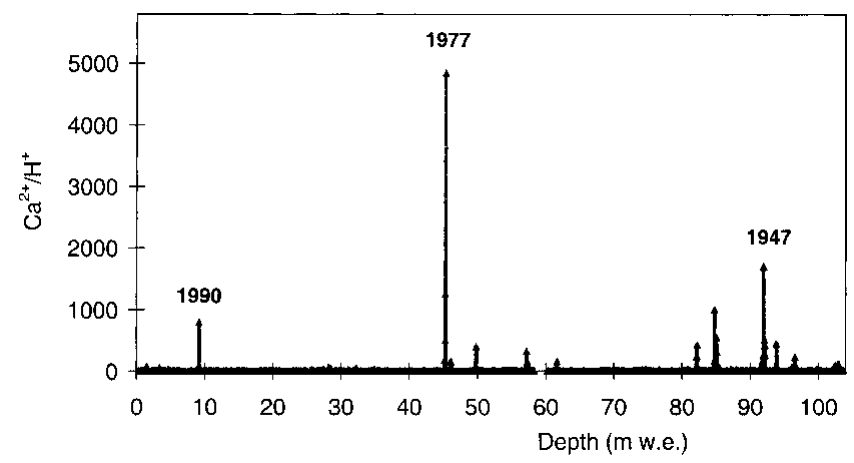

Fig. 9. Identification of strong Saharan dust falls by high $\mathrm{Ca}^{2+} / \mathrm{H}^{+}$concentration ratios.
1990 (Schwikowski and others, 1995), May 1977 (Prodi and Fea, 1978; Wagenbach and Geis, 1989) and 1947 (Wagenbach and Geis, 1989). No additional dust peak was observed in the deepest part of the core, which would have corresponded to the well-known Saharan dust fall in 1936/37 (Wagenbach and Geis, 1989; Döscher, 1996). Thus, the deepest part is not older than 58 years with respect to the drilling date.

\section{${ }^{3}$ Hand ${ }^{137}$ Cs}

Tritium ${ }^{3} \mathrm{H}\left(t_{\frac{1}{2}}=12.3 \mathrm{a}\right)$ is naturally produced in the atmosphere by ${ }^{2}$ the ${ }^{14} \mathrm{~N}\left(\mathrm{n},{ }^{3} \mathrm{H}\right){ }^{12} \mathrm{C}$ reaction of cosmic-rayinduced neutrons with atmospheric nitrogen. ${ }^{3} \mathrm{H}$ is directly incorporated into the water molecule by its reaction with stratospheric oxygen. Natural background tritium levels in precipitation before 1951 are very low, approximately $0.1-1$ $\mathrm{Bq} \mathrm{L}{ }^{-1}$. With the detonation of the world's first thermonuclear explosion by the U.S.A. in May 1951, a period of anthropogenic ${ }^{3} \mathrm{H}$ production began, increasing stratospheric ${ }^{3} \mathrm{H}$ concentrations by several orders of magnitude. The amount of tritium released into the atmosphere during the period 1951-62 was estimated to be about $2.4 \times 10^{14} \mathrm{~Bq}$ (Clark and Fritz, 1997). Until the Soviet-U.S. Test Ban Treaty in 1963, a stratospheric reservoir of ${ }^{3} \mathrm{H}$ was built up, influencing the precipitation composition up to the present.

The radioactive isotope ${ }^{137} \mathrm{Cs}\left(t_{\frac{1}{2}}=30.2 \mathrm{a}\right)$ is, along with ${ }^{90} \mathrm{Sr}\left(t_{\frac{1}{2}}=28.6 \mathrm{a}\right)$, one of the longer-lived nuclear fission products. During the atmospheric nuclear weapon tests in the 1950s and early 1960s (see above), large amounts of ${ }^{137}$ Cs were ejected into the stratosphere with debris. The main portion of ${ }^{137}$ Cs reaches the Earth's surface adsorbed onto aerosol particles with a time delay of a few months to a few years because of the long stratospheric residence time (Emeleus and Sharpe, 1961). Another event increasing the ${ }^{137} \mathrm{Cs}$ activity in the atmosphere was the nuclear reactor accident at Chernobyl on 26 April 1986. Huge amounts of radioactive material were spread over a large area of the Northern Hemisphere, being either transported as gaseous species (e.g. $\mathrm{Kr}$ and $\mathrm{Xe}$ ) or adsorbed onto aerosol particles (e.g. ${ }^{137} \mathrm{Cs}$ ). As a result, increased activity of ${ }^{137} \mathrm{Cs}$ was detected even in Alpine glaciers (Haeberli and others, 1988).

The activities of the isotopes ${ }^{137} \mathrm{Cs}$ and ${ }^{3} \mathrm{H}$ measured along the Grenzgletscher ice core are presented in Figure $10 \mathrm{a}$ and $\mathrm{b}$. Both records reflect the atmospheric weapon tests in the 1950s and 1960s in a broad activity peak at 55-85 $\mathrm{m}$ w.e. depth. The maxima at approximately 76 and $69 \mathrm{~m}$ w.e. depth are related to the test maxima of the years 1958 and 1962. They appear in the ice core with a time delay of approximately 1 year because of the above-mentioned slow stratosphere-troposphere transfer (see, e.g., Emeleus and Sharpe, 1961). For the same reason, activities appear in a broad peak. The maximum of the ${ }^{137}$ Cs activity at $20 \mathrm{~m}$ w.e. depth can be attributed to the radioactive fallout from the nuclear reactor accident at Chernobyl. The tropospheric transport of the aerosol-bound fission products, and their fast removal by wet deposition in the first week of May 1986, yielded a sharp signal in the ${ }^{137}$ Cs activity record.

The integrated ${ }^{137} \mathrm{Cs}$ activity from nuclear weapons fallout $\left(3500 \pm 800 \mathrm{~Bq} \mathrm{~m}^{-2}\right)$ agrees well with estimated values (e.g. $5040 \mathrm{~Bq} \mathrm{~m}^{-2}$ between $40^{\circ}$ and $50^{\circ} \mathrm{N}$ (Kiefer, 1986), or approximately $4500 \mathrm{~Bq} \mathrm{~m}^{-2}$ at Jungfraujoch, Switzerland (von Gunten and Rössler, unpublished)). The calculated ${ }^{137}$ Cs fallout from the Chernobyl accident (800 \pm 200 $\mathrm{Bq} \mathrm{m}^{-2}$ ) is at the lower limit of the values determined at Alpine sites (400-15000 Bq m${ }^{-2}$; Haeberli and others, 1988). 
These differences in the deposited activities reflect the known regional heterogeneity of the Chernobyl fallout, which was strongly dependent on the precipitation pattern in the first days of May 1986.

${ }^{36} \mathrm{Cl}$

${ }^{36} \mathrm{Cl}\left(t_{1 / 2}=301000 \mathrm{a}\right)$ is produced in the atmosphere mainly by the interaction of atmospheric argon with highenergy cosmic radiation in the reaction ${ }^{40} \mathrm{Ar}(\mathrm{p}, \mathrm{n} \alpha){ }^{36} \mathrm{Cl}$. After its formation, the isotope is assumed to be attached to aerosol particles and has a residence time of 1-2 years in the stratosphere (Synal and others, 1990). Once in the troposphere, it is removed by dry or wet deposition. Besides ${ }^{3} \mathrm{H}$ and ${ }^{137} \mathrm{Cs}$ (see above), ${ }^{36} \mathrm{Cl}$ was also produced anthropogenically during the thermonuclear bomb tests in the 1950s. Since anthropogenic ${ }^{36} \mathrm{Cl}$ is formed by the neutron activation of ${ }^{35} \mathrm{Cl}$ of sea water, the highest ${ }^{36} \mathrm{Cl}$ activity was released into the atmosphere during tests taking place on ships or to a smaller extent on islands. Most tests on ships were performed in 1954, 1956 and 1958, releasing an overall amount of about $78 \mathrm{~kg}{ }^{36} \mathrm{Cl}$ (Synal and others, 1990).

The ice-core ${ }^{36} \mathrm{Cl}$ record from Grenzgletscher is presented in Figure 10c. The broad activity peak at 60-82 $m$ w.e. depth reflects the production by atmospheric weapon tests in the 1950s. ${ }^{36} \mathrm{Cl}$ concentrations show a strong increase between 82 and $78 \mathrm{~m}$ w.e., reaching concentrations about two orders of magnitude higher at the maximum in 1958 compared to the natural pre-bomb level. After 1958 a rapid decline can be observed, indicating that the main atmospheric tests over land from 1962, which led to the maxima in the ${ }^{3} \mathrm{H}$ and ${ }^{137} \mathrm{Cs}$ activities, did not strongly influence the ${ }^{36} \mathrm{Cl}$ concentration in the atmosphere. The surprisingly high ${ }^{36} \mathrm{Cl}$ concentrations at $92-100 \mathrm{~m}$ w.e. depth can currently not be explained.

In order to determine the overall input of bomb-produced ${ }^{36} \mathrm{Cl}$, we integrated the measured inventory between 60 and $82 \mathrm{~m}$ w.e. with an assumed annual average precipitation rate of $2.7 \mathrm{~m}$ w.e. $\mathrm{a}^{-1}$ and derived a value of $(4.5 \pm 0.8) \times 10^{12}$ atoms $\mathrm{m}^{-2}$. The fallout of bomb-produced ${ }^{36} \mathrm{Cl}$ was estimated, using a box model for the atmospheric transport of radionuclides (Sachsenhauser and others, 1997). The maximum of approximately $4.6 \times 10^{12}$ atoms $\mathrm{m}^{-2}$ of the ${ }^{36} \mathrm{Cl}$ inventory was obtained in the mid-latitudes, between 40 and $50^{\circ} \mathrm{N}$, whereas the minima for the Northern Hemisphere were reached at the Equator and at the North Pole with about $1 \times 10^{12}$ atoms $\mathrm{m}^{-2}$. The ${ }^{36} \mathrm{Cl}$ inventory determined at Grenzgletscher (about $\left.45^{\circ} \mathrm{N}\right)$ fits well with the model results.

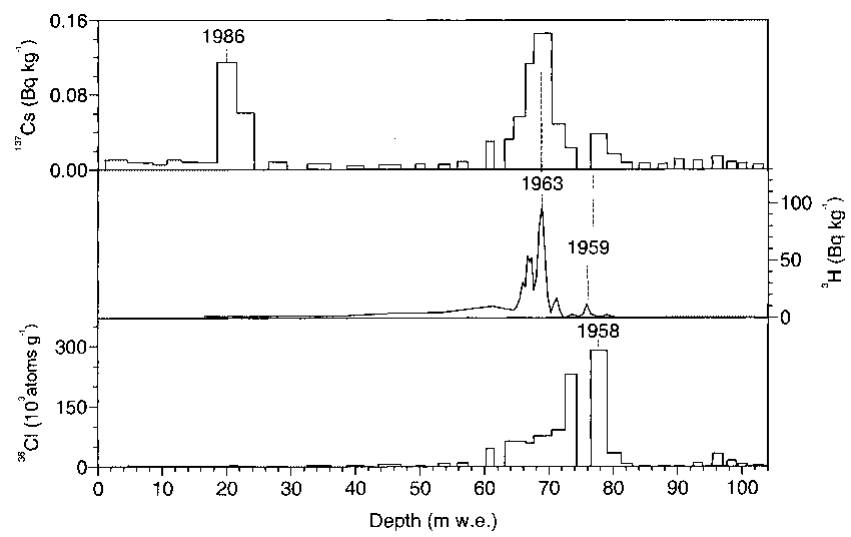

Fig. 10. Records of the ${ }^{137} \mathrm{Cs}(a)$ and ${ }^{3} H(b)$ activities and ${ }^{36} \mathrm{Cl}$ concentration (c) vs depth of the ice core; the activities were calculated back to the date of drilling in October 1994.
All stratigraphic markers depicted in Figures 9 and 10 agree well with the already established age-depth relationship (see Fig. 7). By combining all methods used, the accuracy of dating was improved, resulting in an uncertainty of $<1$ year for the period 1970-94 and \pm 2 years for the period 1937-69.

\subsection{Determination of the thinning effect}

Figure 11 shows the age-depth relationship resulting from a combination of all methods described above (triangles). The included linear trend line (dashed line), which represents a constant annual-layer thickness $\lambda$ of $2.7 \mathrm{~m}$ w.e., describes the data only in the upper $50 \mathrm{~m}$ w.e. With increasing depth the data differ more from this line and show a steeper slope. This means that the annual layer thickness (1/slope) decreases as a function of depth, due to an increasing vertical strain of the glacier ice with depth. The thinning in the deepest core parts amounts to about $60 \%$, corresponding to an annual layer thickness $\lambda_{\mathrm{E}}$ of $1 \mathrm{~m}$ w.e. in comparison to the initial value $\lambda_{0}$ of $2.7 \mathrm{~m}$ w.e.

For the description of the observed thinning effect, a simple kinematic ice-flow model developed by Nye (Haefeli 1961; Nye, 1963; Dansgaard and Johnsen, 1969) was used. This model implies a uniform vertical strain rate and therefore a constant horizontal velocity along any vertical line in an ice cap. Melting at the bottom is assumed to be negligible. The age $t$ of a layer $y$ below the surface can be calculated from the absolute ice thickness $H$ and from the initial annual layer thickness $\lambda_{0}$ :

$$
t=\frac{H}{\lambda_{0}} \ln \left(\frac{H}{H-y}\right) .
$$

This one-dimensional pure kinematic flow model does not take into account any dynamical ice-flow law. Nevertheless, Nye's model was successfully applied to the estimation of time-scales covered by Greenland ice cores down to depths of about $2 / 3 H$ (Hammer and others, 1978). The calculated age-depth relationship for the Grenzgletscher core with $\lambda_{0}$ $=2.7 \mathrm{~m}$ w.e. and $H=170 \mathrm{~m}$ w.e. (see section 2.2) is shown in Figure 11 (solid line). The agreement with the established dating based on chemical records is remarkably good. Possible reasons for the applicability of Nye's model are that the investigated ice core represents only about two-thirds of the total glacier thickness and that Grenzgletscher has a relatively

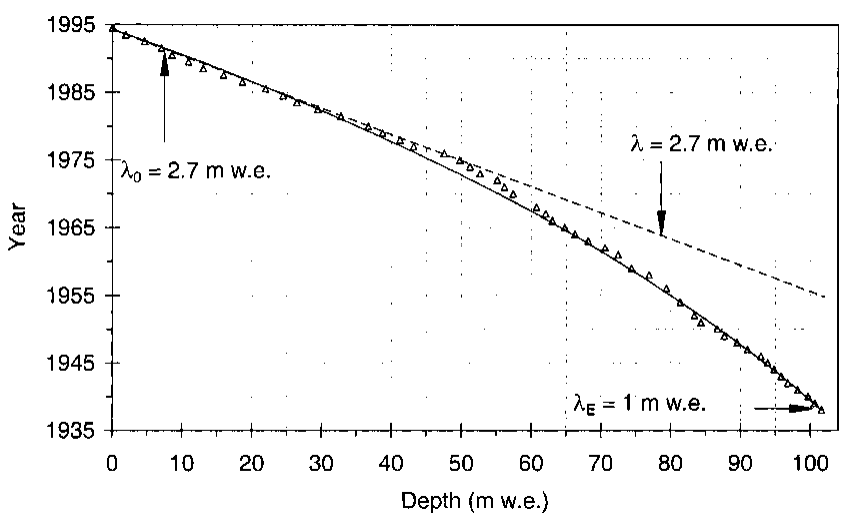

Fig. 11. Age-depth relationship established in this work (triangles), together with a line representing a constant annual-layer thickness of $\lambda=2.7 \mathrm{~m}$ w.e. (dashed line). In addition, the age-depth relationship after $\mathcal{N y e ' s ~ m o d e l ~ i s ~ g i v e n ~}$ (solid line) with $\lambda_{0}=2.7 \mathrm{~m}$ w.e. and $H=170 \mathrm{~m}$ w.e., describing the thinning of the annual layers with depth from $\lambda_{0}$ to $\lambda_{\mathrm{E}}=1$ m w.e. 
simple topography with a proportionally large extent and a small slope in the drilling area.

In order to take into account the annual-layer thinning with depth, the ${ }^{210} \mathrm{~Pb}$ data were re-analyzed. The simple linear regression of the logarithmic activities vs depth (see section 3.1; Fig. 6, solid line) yields an inaccurate average annual-layer thickness of $1.9 \mathrm{~m}$ w.e. In order to include thinning, the age-depth relationship derived from Equation (1) and shown in Figure 11 was added in Figure 6 (dashed line). This curve fits the experimental data better $\left(\chi^{2}=1\right)$ than the linear regression $\left(\chi^{2}=1.5\right)$.

\section{SUMMARY AND CONCLUSIONS}

Different techniques were used to date an Alpine ice core derived from a glacier site with high annual net accumulation rates. We obtained a time period covered by the ice core of 1937-94. Dating by the radioactive decay of ${ }^{210} \mathrm{~Pb}$ gave a first approximation of the chronology with an uncertainty of about 7 years. This uncertainty was caused by variations in the ${ }^{210} \mathrm{~Pb}$ input and by thinning of annual layers with depth. Equally high uncertainties resulted from the annual-layer counting using individual seasonal tracers. Cumulative dating errors of 12-24 years and of about 6 years were obtained from counting $\mathrm{NH}_{4}{ }^{+}$and $\delta^{18} \mathrm{O}$ layers, respectively. By a combined analysis of both seasonal tracers the dating accuracy was improved significantly to \pm 1 year for the period 1970-94 and \pm 3 years for the period 1937-69. With the additional use of reference horizons from Saharan dust falls (1947, 1977 and 1990), the atmospheric nuclear weapon tests in the 1950s and early 1960s and the reactor accident at Chernobyl (1986), the uncertainty was further reduced to $<1$ year for the period 1970-94 and \pm 2 years for the period 1937-69. The thinning of the annual layers was well described by a simple kinematic glacier flow model. The accurately dated glaciochemical records from Grenzgletscher will now make it possible to investigate north-south gradients of the deposition of air pollutants in the Alps.

These results imply that an accurate dating even of smallscale Alpine glaciers is possible whenever precipitation is seasonally distributed and preserved. In this case the multiparametric approach using seasonal tracers and stratigraphic markers is a very reliable dating method. Even at glacier sites where seasonal precipitation is missing or disturbed by wind drift and erosion, a chronology can be established with the ${ }^{210} \mathrm{~Pb}$ method, although it is less accurate. A good approximation of the time-scale for the upper two-thirds of such an ice core can also be obtained by simple glacier flow modelling. Both dating with ${ }^{210} \mathrm{~Pb}$ and flow modelling might be improved by identifying temporal horizons of particular events.

\section{ACKNOWLEDGEMENTS}

We thank T. Blunier, T. Döring, A. Döscher, V. Lavanchy, H. Rufli and J. Schwander for their engagement in the field and D. Vonder Mühll, A. Kääb, M. Laternser, S. Suter and B. Suter for the glaciological investigations. The assistance of R. Siegwolf, K. Bleidissl and E. Rössler with the $\delta^{18} \mathrm{O}$ analyses is gratefully acknowledged. We thank C. Stengel and $\mathrm{S}$. Brütsch for their help with sample preparation for the ${ }^{36} \mathrm{Cl}$ analyses, A. Lück for the ${ }^{137} \mathrm{Cs}$ measurements, and U. Schotterer and H. Bürki for tritium analyses. The generous support of the Aargauische Zentralmolkerei, Suhr, in storing the ice cores is much appreciated. We thank L. Tobler and N. Streit for useful comments, and S. Nyeki for carefully reading the manuscript. This work was partly supported by the Swiss National Science Foundation (project NFP-31). The comments of the two anonymous reviewers improved the clarity of the paper, and we are grateful for their suggestions.

\section{REFERENGES}

Asman, W. A. H. 1992. Ammonia emission in Europe: updated emission and emission variations. Bilthoven, National Institute of Public Health and Environmental Protection. (Report 228471008.)

Clark, I. D. and P. Fritz. 1997. Environmental isotopes in hydrogeology. New York, GRC Lewis.

Dansgaard, W. 1964. Stable isotopes in precipitation. Tellus, 16(4), 436-468.

Dansgaard, W. and S. J. Johnsen. 1969. A flow model and a time scale for the ice core from Camp Century, Greenland. F. Glaciol., 8(53), 215-223.

Dansgaard, W., S. J. Johnsen, H. B. Clausen and N. Gundestrup. 1973. Stable isotope glaciology. Medd. Grønl., $197(2)$.

De Angelis, M. and A. Gaudichet. 1991. Saharan dust deposition over Mont Blanc (French Alps) during the last 30 years. Tellus, 43B(1), 61-75.

Döscher, A. 1996. Historische Entwicklung von atmosphärischen Spurenstoffkonzentrationen rekonstruiert aus Firn und Eis alpiner Gletscher. (P.D. thesis, University of Bern.)

Döscher, A., M. Schwikowski and H.W. Gäggeler. 1995a. Cation trace analysis of snow and firn samples from high-Alpine sites by ion chromatography. $\mathcal{F}$. Chromatogr., Ser. A, 706(1-2), 249-252.

Döscher, A., H.W. Gäggeler, U. Schotterer and M. Schwikowski. 1995b. A 130 years deposition record of sulfate, nitrate and chloride from a highAlpine glacier. Water, Air, Soil Pollut., 85(2), 603-609.

Döscher, A., H.W. Gäggeler, U. Schotterer and M. Schwikowski. 1996. A historical record of ammonium concentrations from a glacier in the Alps. Geophys. Res. Lett., 23(20), 2741-2744.

Eichler, A. Unpublished. Bohrung, Aufarbeitung und Datierung eines alpinen Eisbohrkernes vom Grenzgletscher (Monte Rosa Massiv, 4200 mü.M.). Villigen, Paul Scherrer Institut. (Interner Bericht TM-18-99-04.)

Eichler, A., M. Schwikowski and H.W. Gäggeler. In press. Meltwater induced relocation of chemical species in Alpine firn. Tellus.

Emeleus, H. J. and A. G. Sharpe. 1961. Advances in inorganic chemistry and radiochemistry. Vol. 3. New York, Academic Press.

Epstein, S. and T. Mayeda. 1953. Variation of $\mathrm{O}^{18}$ content of waters from natural sources. Geochim. Cosmochim. Acta, 4(5), 213-224.

Füeg, B. Unpublished. Datierung des "blauen” Eiscores mit ${ }^{210} \mathrm{~Pb}$. Villigen, Paul Scherrer Institut. (Interner Bericht TM-32-94-01. Diplomarbeit.)

Gäggeler, H.W. 1995. Radioactivity in the atmosphere. Radiochim. Acta, 70/71, 345-353.

Gäggeler, H., H. R. von Gunten, E. Rössler, H. Oeschger and U. Schotterer. 1983. ${ }^{210} \mathrm{~Pb}$-dating of cold Alpine firn/ice cores from Colle Gnifetti, Switzerland. f. Glaciol., 29 (101), 165-177.

Gäggeler, H., B. Stauffer, A. Döscher and T. Blunier. 1997. Klimageschichte im Alpenraum aus Analysen von Eisbohrkernen. Zürich, ETH. Vdf Hochschulverlag AG. (Schlussbericht NFP 31.)

Haeberli, W., H. Gäggeler, U. Baltensperger, D. Jost and U. Schotterer. 1988. The signal from the Chernobyl accident in high-altitude firn areas of the Swiss Alps. Ann. Glaciol., 10, 48-51.

Haefeli, R. 1961. Contribution to the movement and the form of ice sheets in the Arctic and Antarctic. F. Glaciol., 3(30), 1133-1151.

Hammer, C. U., H. B. Clausen, W. Dansgaard, N. Gundestrup, S. J. Johnsen and N. Reeh. 1978. Dating of Greenland ice cores by flow models, isotopes, volcanic debris, and continental dust. f. Glaciol., 20 (82), 3-26.

Johnsen, S. J. 1977. Stable isotope homogenization of polar firn and ice. International Association of Hydrological Sciences Publication 118 (Symposium at Grenoble 1975 - Isotopes and Impurities in Snow and Ice), 210-219.

Kiefer, H. 1986. Die Auswirkungen des Reaktorunfalls in Tschernobyl auf die Bevölkerungsdosis. KfK-Nachrichten 18, 133-134.

Lavanchy, V. M. H., H.W. Gäggeler, U. Schotterer, M. Schwikowski and U. Baltensperger. 1999. Historical record of carbonaceous particle concentrations from a European high-alpine glacier (Colle Gnifetti, Switzerland). F. Geophys. Res., 104(D17), 21,227-21,236.

Lugauer, M. and 6 others. 1998. Aerosol transport to the high Alpine sites Jungfraujoch (3454 ma.s.l.) and Colle Gnifetti (4452 ma.s.1.). Tellus, 50B, 76-92.

Maupetit, F., D. Wagenbach, P. Weddeking and R. J. Delmas. 1995. Seasonal fluxes of major ions to a high altitude cold alpine glacier. Atmos. Environ., $29(1), 1-9$.

Nye, J. F. 1963. Correction factor for accumulation measured by the thick- 
ness of the annual layers in an ice sheet. 7. Glaciol., 4(36), 785-788.

Oeschger, H., U. Schotterer, B. Stauffer, W. Haeberli and H. Röthlisberger. 1978. First results from Alpine core drilling projects. Z. Gletscherkd. Glazialgeol., 13(1-2), 1977, 193-208.

Pfister, C. 1999. Wetternachhersage. Bern, Paul Haupt Verlag.

Prodi, F. and G. Fea. 1978. Transport and deposition of Saharan dust over Alps. I. Teil des Tagungsberichtes der 15 Internationalen Tagung für Alpine Meteorologie, 19-23 September 1978, Grindelwald. Schweiz. Meteorol. Zentralanstalt Veröff., 40, 179-182.

Sachsenhauser, H., L. Zerle, J. Beer, J. Masarik and E. Nolte. 1997. Atmospheric transport of cosmogenic radionuclides. In Glaciers from the Alps: climate and environmental archives. Proceedings of the Wengen Workshop, 21-23 October 1997, Wengen. Villigen PSI, Paul Scherrer Institute, 103-114.

Savarino, J. and M. Legrand. 1998. High northern latitude forest fires and vegetation emissions over the last millennium inferred from the chemistry of a central Greenland ice core. 7. Geophys. Res., 103(D7), 8267-8279.

Schotterer, U. and 7 others. 1977. Isotope measurements on firn and ice cores from alpine glaciers. International Association of Hydrological Sciences Publication 118 (Symposium at Grenoble 1975 - Isotopes and Impurities in Snow and Ice), 232-236.

Schotterer, U., H. Oeschger, D. Wagenbach and K. O. Münnich. 1985. Information on paleo-precipitation on a high-altitude glacier Monte Rosa, Switzerland. Z Gletscherkd. Glazialgeol., 21, 379-388.

Schotterer, U., K. Fröhlich, H.W. Gäggeler, S. Sandjordj and W. Stichler. 1997. Isotope records from Mongolian and Alpine ice cores as climate indicators. Climatic Change, 36, 519-530.

Schotterer, U., P. Schwarz and V. Rajner. 1998. From pre-bomb levels to industrial times. A complete tritium record from an Alpine ice core and its relevance for environmental studies. In Isotope techniques in the study of environmental change. Vienna, International Atomic Energy Agency, 581-590. (Proceedings Series.)

Schütz, L. and M. Sebert. 1987. Mineral aerosols and source identification. 7. Aerosol Sci., 18(1), 1-10.

Schwikowski, M., P. Seibert, U. Baltensperger and H.W. Gäggeler. 1995. Study of an outstanding Saharan dust event at the high-Alpine site Jungfraujoch, Switzerland. Atmos. Environ., 29(15), 1829-1842.

Schwikowski, M., A. Döscher, H. Gäggeler and U. Schotterer. 1999a. Anthropogenic versus natural sources of atmospheric sulphate from an
Alpine ice core. Tellus, 51B(5), 938-951.

Schwikowski, M., S. Brütsch, H. Gäggeler and U. Schotterer. 1999b. A highresolution air chemistry record from an Alpine ice core: Fiescherhorn glacier, Swiss Alps. F. Geophys. Res., 104(D11), 13,709-13,719.

Synal, H.-A., J. Beer, G. Bonani, M. Suter and W. Wölfli. 1990. Atmospheric transport of bomb-produced ${ }^{36} \mathrm{Cl}$. Nucl. Instrum. Methods Phys. Res., Ser. B, 52, 483-488.

Synal, H.-A., J. Beer, G. Bonani, Ch. Lukasczyk and M. Suter. $1994 .{ }^{36} \mathrm{Cl}$ measurements at the Zürich AMS facility. Nucl. Instrum. Methods Phys. Res., Ser. B, 92(1-4), 79-84.

Synal, H.-A. and 7 others. 1997. Status report of the PSI/ETH AMS facility. Nucl. Instrum. Methods Phys. Res., Ser. B, 123, 62-68.

Vonder Mühll, D. S. and M. Funk. Unpublished. Gletscherdickenbestimmung mittels Radar auf dem Grenzgletscher, Monte Rosa Massiv. Zürich, Eidgenössische Technische Hochschule. Versuchsanstalt für Wasserbau, Hydrologie und Glaziologie (Interner Bericht).

Von Gunten, H. R. and R. N. Moser. 1993. How reliable is the ${ }^{210} \mathrm{~Pb}$ dating method? Old and new results from Switzerland. F. Paleolimnol., 9, 161-178.

Von Gunten, H. R. and E. Rössler. Unpublished. Datierung eines Eisbohrkernes vom Colle Gnifetti (Monte Rosa) mit ${ }^{90} \mathrm{Sr},{ }^{90}$ Yand ${ }^{137} \mathrm{Cs}$. Villigen, Paul Scherrer Institut. (Interner Bericht TM-CH-202.)

Von Gunten, H. R., E. Rössler and H. Gäggeler. 1983. Dating of ice cores from Vernagtferner (Austria) with fission products and lead-210. Z. Gletscherkd. Glazialgeol., 18(1), 1982, 37-45.

Wagenbach, D. and K. Geis. 1989. The mineral dust record in a high altitude Alpine glacier (Colle Gnifetti, Swiss Alps). In Leinen, M. and M. Sarnthein, eds. Paleoclimatology and paleometeorology: modern and past patterns of global atmospheric transport. Dordrecht, etc., Kluwer Academic Publishers, 543-564. (NATO ASI Series C: Mathematical and Physical Sciences 282.)

Wagenbach, D., K. O. Münnich, U. Schotterer and H. Oeschger. 1988. The anthropogenic impact on snow chemistry at Colle Gnifetti, Swiss Alps. Ann. Glaciol., 10, 183-187.

Wanner, H., R. Rickli, E. Salvisberg, C. Schmutz and M. Schüepp. 1997. Global climate change and variability and its influence on Alpine climate - concepts and observations. Theor. Appl. Climatol., 58, 221-243.

MS received 17 November 1999 and accepted in revised form 9 May 2000 